\title{
Polak w rosyjskim mundurze. Próba komentarza do itinerarium Wincentego Kamieńskiego
}

Iwona $\mathrm{W}$ iśniewska 
nAP7S Seria V 1999

\section{Iwona Wiśniewska}

\section{Polak w rosyjskim mundurze. Próba komentarza do itinerarium Wincentego Kamieńskiego}

\section{Historia}

$\mathrm{T}$ ckst powyższy został początkowo wydobyty na światło dzienne i opracowany jedynie ze względu na wnuczkę autora, którą była Eliza Orzeszkowa. Wincenty Kamieński był ojcem Franciszki Pawłowskiej, matki Elizy. Wstęp do sylwy miał służyć tylko jako komentarz do części genealogicznej Kalendarium ̇̇ycia i twórczości autorki Nad Niemnem. Jednakże zarówno legenda, jaką dopisała swemu macierzystemu przodkowi Orzeszkowa, jak i walory tej krótkiej wojennej odysei kazały przyjrzeć się bliżej historii opowiedzianej przez Wincentego Kamieńskiego.

W życiu każdego człowieka bardzo ważne jest poczucie pewności tego, co robi. Nie chodzi tu o cel działania czy ideę, jaka temu działaniu przyświeca, ale czy to, co robimy, przychodzi nam bez zmęczenia i wątpliwości. Jak się zdaje, autor sylwy nie zastanawiał się nad słusznością czynu, jakim było przywdzianie munduru oficera gwardii Aleksandra I. Wstąpił do wojska mając w sobie zapewne młodzieńczy głód świata. Wincenty Kamieński był na tyle pewny tego, co robi, żc nie skupiał się na pobudkach działania, ale na samym działaniu. Nie był to na pewno homo politicus posiadający pasję polemiczną, ale poczciwy żołnierz. Nie kondotier jednak, gdyż — choć nie Rosjanin — Kamieński utożsamiał się ze sprawą, o którą walczyła armia cesarza Aleksandra. Nie czuł się najemnym grenadierem.

Wincenty Kamieński urodził się prawdopodobnie w przedostatnim dziesiątku XVIII wicku na Litwie. Wiemy, że był właścicielem majątku Michałówka w guberni grodzieńskiej, jednak nie sposób dociec, czy była to własność rodowa, nabyta czy też posag żony Wincentego, Elżbiety z Kaszubów. Swą macierzystą babkę wspominała Orzeszkowa czę- 
sto i ciepło, dziadka zaś nie znała, zmarł przed jej urodzeniem. W metryce chrztu Elizy Elżbieta Kamieńska figuruje jako wdowa. Jaka mogła być historia Wincentego? Tych kilka słów, w których zawiera swój życiorys do czasu wstąpienia do armii, przypomina raczej fragment urzędowego dokumentu: miejsce urodzenia - gubernia grodzieńska, „rodzice szlachetni", zapewne posesjonaci, gdyż Wincenty wspomina o rodowym majątku, do którego wrócił po otrzymaniu dymisji z armii. Nie wiemy, czy decyzję o wstąpieniu do armii podjęli za niego rodzice (opiekunowie?) czy był to jego własny wybór. Droga kariery wojskowej w armii zaborcy nie była w I połowie XIX wieku czymś deprecjonującym dla Polaka. W Europie wielu żołnierzy zmieniało kolor munduru. Można tu przywołać wymienianego przez Kamieńskiego Włocha, Filipa Paulucci, który służył u Austriaków, Francuzów i Rosjan.

Gdy Kamieński odbywa szlak bojowy pod sztandarami Aleksandra I, tysiące Polaków walczy w armii Napoleona, z nim wiążąc nadzieje na zmianę porządku politycznego w Europie. Dziś można zadawać pytanie, czyj wybór był słuszny. Wszak Aleksander I, choć samodzierżawca i zaborca, bronił jedynie status quo, natomiast Napoleon był najeźdźcą stojącym wobec większości krajów Europy na pozycji takiej samej, jak Rosja wobec Polski. Poza tym ów samozwańczy cesarz nie cieszył się zaufaniem szlachty przyzwyczajonej do porządku stanowego. Syn asesora sądowego, niejakiego Buonaparte z Ajaccio, zasiadający na tronie budził niesmak.

Kiedy Jan Henryk Dąbrowski i książę Józef Poniatowski kontynuowali tradycje walki zbrojnej, książę Adam Jerzy Czartoryski wierzył w siłę drogi dyplomatycznej. Był zwolennikiem i propagatorem idei restytuowania państwa przez uczestnictwo Polaków w realizacji antynapoleońskiej polityki rosyjskiej. Liberalne gesty Aleksandra I pozwalały na opracowanie programu tzw. Ligi Europejskiej, czyli federacji mniejszych państw jako przeciwwagi dla hegemonii francuskiej. Postać Czartoryskiego jest dziś dla historyków dwuznaczna — przyjaciel młodego Aleksandra, rosyjski dworak, który złożył przysięgę na wierność carowi po to, by ratować kresowe latyfundia rodzinne, polityk bardziej rosyjski niż polski, związany mocno z petersburskim dworem. Jednak lansowana za jego sprawą koncepcja zaistnienia Polski na mapie politycznej przetrwała klęskę Napoleona. Stanisław Staszic, prezes Warszawskiego Towarzystwa Przyjaciół Nauk snuł w wygłoszonym w sierpniu 1815 roku odczycie rozważania o europejskiej wspólnocie Słowian, która zapewniłaby wieczną równowagę w Europie, skutecznie i na zawsze już zagradzając drogę ekspansji Teutonom (żywioł germański) i Gaulolatynom (żywioł romański):

Wśród całego słowiańskiego pokolenia w największe społeczeństwa skupionymi były dwa narody: polski i rosyjski. Te dwa narody od kilku wieków bądź przez własne kłótnie, bądź przez Niemców skryte wpływy i poduszczenia toczyli między sobą wojny ciągłe i niszczyli się wspólnie. (...) 
(...) niezłomną tegoż narodu Polaków dążnością do połączenia się z swoimi braćmi, do spolenia się z nimi przynajmniej w sławiańskim rodzie, wszczęła siç pierwszy raz w Sławianach [w wieku XVIII - I. W.] myśl połączenia i zrzeszenia się narodów najogromniejszego na tej ziemi sławiańskiego pokolenia. (...) Myśl ta od jej wszczęcia wśród rozszarpanych Polaków już do znacznego dochodzi wzrostu. (...) Zginie, kto będzie przeciw niej. (...)

Polacy są nieudolni być waszymi [Rosjan - I. W.] niewolnikami, ale są przygotowani stać się waszymi braćmi. Połączcież ten naród z właściwą mu ustawą narodowego prawa i rządu pod jednym cesarzem i królem w wielką rzeszę Cesarstwa ${ }^{1}$.

Staszic widzi Rosję jako jedynego zaborcę, który „zjednał sobie ogólną chęć” Polaków zachowując ich język, narodowe urzędy i wychowanie dzieci w ojczystym języku. Przeciwstawia rosyjskim braciom teutońskich polakożerców, których pierwszym zamiarem jest przeistoczenie naszych rodaków w Niemców.

Dość żywa ówcześnie prorosyjska koncepcja odzyskania państwa obecnie istnieje jedynie w podręcznikach historii, natomiast literatura skłoniła się ku mitowi Napoleona. Próbując osądzać wybory dokonywane przez Polaków na początku XIX wieku warto jednak zwrócić uwagę, że sam rozwój wydarzeń wojennych powodował paradoksy. Przypomnijmy chociażby rok 1812. Po wkroczeniu Wielkiej Armii na Litwę doszło tam niemal do wybuchu powstania chłopskiego. Ludność litewska i białoruska wiązała z przyjściem Napolcona nadzieje na poprawę swej doli. Ale zamiast wstępować do armii, odmawiano wykonywania pańszczyzny i napadano na dwory. Szlachta musiała walczyć z chłopami wszczynającymi bunty z imieniem cesarza Francuzów na ustach. Wtedy więc, z punktu widzenia swego stanu, Wincenty Kamieński stał po słusznej stronie. Bronił ustalonego porządku społecznego.

Jego służbę w pułku keksholmskim potwierdzają dokumenty z Rosyjskiego Państwowego Archiwum Wojskowo-Historycznego w Moskwie ${ }^{2}$. Rozkaz zaliczenia go do liczby podoficerów lejbgwardyjskiego keksholmskiego pułku muszkieterów pochodzi z 6 września (starego stylu) 1804 roku. Do rozkazu dołączony jest paszport na nazwisko Wincentego Kamieńskiego, syna Piotra, wydany przez zarząd guberni litewsko-grodzieńskiej. Dowiadujemy się, iż przed wstąpieniem do armii Wincenty był urzędnikiem administracji cywilnej. Od 31 lipca (st. st.) 1803 r. do 9 sierpnia (st. st.) 1804 r. pracował na etacie rejestratora gubernialnego w grodzieńskiej izbie skarbowej. Wydane przez izbę skarbową świadectwo informuje, iż Kamieński pochodzący z litewskiej szlachty pracował już wcześniej w służbie cywilnej, obowiązki swe w izbie skarbowej wypełniał sumiennie i gorliwie, prowadził sic̨ uczciwie i przyzwoicie, nie był nigdy o nic oskarżony ani też nie płacił kar z żadnego tytułu.

\footnotetext{
' S. Staszic, Mysli o róunnowadze politycznej w Europie [w:] tenże, Pisma filozoficzne ispoleczne, opr. B. Suchodolski, t. 2, Warszawa 1954, s. 316-319.

${ }^{2}$ Fond 2875 Keksholmski pulk piechoty, opis 3/172, teczka 7, sprawa 12.
} 
Kamieński pisze, iż otrzymał dymisję w lipcu 1813 roku. Tymczasem w spisach oficerów i żołnierzy pułku keksholmskiego za 1812 r. jego nazwisko nie figuruje. Spisów za lata 1805-1811 i 1813 w Archiwum brak.

Dokumenty pułkowe potwierdzają wszystkie wojenne marszruty, o których wspomina w swym itinerarium Kamieński: w latach 1805-06 desant na Rugii, osłona Hanoweru i twierdzy Hameln, pochód przez księstwa Meklemburgia-Schwerin i Meklemburgia-Strelitz oraz działania w Prusach, w roku 1807 marsz do Prus, w 1808 wyprawa do Finlandii, w 1809 uczestnictwo w ekspedycji alandzkiej, w 1812 udział w bitwach m.in. pod Smoleńskiem i Borodino. W styczniu 1813 pułk wszedł do Księstwa Warszawskiego.

Jednym z najciekawszych fragmentów opowieści Kamieńskiego jest relacja z morskiej wyprawy korpusu generała Tołstoja i jego marsz na Hanower. Są to dość mało znane wydarzenia, bowiem stanowiły właściwie kulisy głównego teatru wojny. W książce wojskowego historyka rosyjskiego, generała Aleksandra Michajłowskiego-Danilewskiego Opisanie pierwoj wojny imperatora Aleksandra s Napoleonom w 1805-m godu (Sanktpeterburg 1844), który opierał się nie tylko na dokumentach i raportach, ale także na relacjach naocznych świadków, odnajdujemy potwierdzenie opowiedzianej przez Kamieńskiego historii niezbyt fortunnej morskiej odysei z roku 1805 (Kamieński pomylił jedynie daty, podając rok 1806).

12 września 1805 roku z portu kronsztadzkiego i rewelskiego wyruszył korpus składający się z ponad 20 tys. żołnierzy, dowodzony przez hrabiego Tołstoja. Rosja nie była pewna, po czyjej stronie opowiedzą się Prusy. W razie gdyby Karol Pruski zezwolił armii Michelsona na przemarsz przez swoje terytorium ku wschodnim terenom Niemiec, hrabia Tołstoj miał się z nią połączyć. Gdyby zaś dwór berliński nie wyraził zgody na przemarsz Rosjan przez Prusy, Tołstoj miał wejść na ich terytorium i posuwać się naprzód. Sztab rosyjski przewidywał jeszcze inną możliwość: gdyby Prusy wypowiedziały Rosji wojnę, admirał Tet miał wysadzić korpus Tołstoja na wybrzeżu Szwedzkiej Pomeranii, potem podpłynąć ku brzegom pruskim i zagrozić desantem, wiążąc tym samym siły Prus. Flota rosyjska miała także przeszkadzać w handlu zamorskim Prus blokując wstęp do portów i przechwytując pruskie statki handlowe. Gdy więc Wincenty Kamieński wypływał w morze, nie wiedział, z kim Rosja będzie prowadziła wojnę. Losy i marszruta wyprawy były niepewne. Wśród pułków, które zostały zaokrętowane w Kronsztadzie, był pułk keksholmski dowodzony przez gen. Werderewskicgo. Flota składała się z 12 okrętów (wśród których znajdował się Rafael czy też Św. Rafat) na którym płynął pułk Kamieńskiego), ośmiu fregat i kilku mniejszych jednostek. Początkowo podróż morska przebiegała pomyślnie, jednak pod koniec rejsu burza rozproszyła flotę. Utonęlo ponad 400 kozaków i kilka dział. Niektóre okręty rozbiły się o pobliskie wysepki. Gdy morze ucichło, okręty przybijały do brzegu w różnych miejscach Szwedzkicj Pomeranii i Rugii, i wysadzały wojsko, które skupiało się w pobliżu Stralsundu.

Wkrótce po przybyciu hrabiego Tołstoja do Stralsundu sprawy przybrały obrót wygodny dla Rosji. Karol Pruski zawarł z Aleksandrem I porozumienie. Korpus rosyjski pomaszerował w listopadzie (1805) na Hanower, wolny od Francuzów, którzy okupowali twierdzę Hameln. 
Korpus przeprawił się przez Łabę w Lauenburgu. Książęta niemieccy przyjmowali Rosjan serdecznic, w wic̨kszych miastach wydawano bale dla kadry oficerskiej. Po przybyciu do Hanoweru, Tołstoj rozmicścił wojska na prawym brzegu Wezery, zaś straż przednią korpusu na prawym. Oczekiwano Anglików. W pobliżc zajętej przez Francuzów twierdzy Hameln posłano oddział dowodzony przez Werderewskiego. Wśród żołnierzy mających obserwować Hameln znajdował się prawdopodobnie Wincenty Kamicński.

20 listopada (st. st.) do głównej kwatery rosyjskiego korpusu przybyli Anglicy: generał Donne i lord Catcarth z wiadomościa, że ich dwa korpusy (w liczbie ok. 24 tys. żołnierzy) znajdują się już u ujścia Wezery. Naczelne dowództwo nad zjednoczonymi siłami objął Tołstoj i z jego rozkazu Anglicy skicrowali się ku Bremic.

Gustaw Adolf, król Szwecji, także w końcu wystąpił z 12 tys. żołnierzy. Szwedzi przeszli przez Łabę i zatrzymali się w Luneburgu. W ten sposób na wschodzie Niemiec powstała armia złożona z 56 tys. żołnierzy rosyjskich, angielskich i szwedzkich. Dalszy marsz był niemożliwy ze względu na rozmokłe drogi. Planowano na razie bronić przepraw przez Ems, gdy zaś szlaki zetnie mróz, iść w dół Renu. Postanowienia te podjęli w Luneburgu wspólnie król szwedzki, Tołstoj, Donne i Catcarth. Ledwo jednak skończyła się narada wojenna, przybył posłaniec z wiadomością o zwycic̨stwie Francuzów pod Austerlitz. Oficerowie z początku nie wierzyli w doniesienia o klęsce. Wiadomość o Austerlitz zniweczyła poprzednie plany. Tołstoj otrzymał rozkaz stanąć pod rozkazami króla Prus. Gustaw Adolf przerzucił swoje wojska na prawy brzeg Łaby, Anglicy otrzymali z Londynu rozkaz odwrotu. Tak rozpadła sic̨ istniejąca zaledwic kilka dni armia wschodnia i nadzieje z nią związane.

Podczas wyprawy hanowerskiej Kamieński nie miał prawdopodobnie okazji wojować. Czas spędzał głównie w marszu i na imprezach organizowanych przez niemieckich książąt dla rosyjskiego korpusu oficerskiego. Sam wspomina o kilku utarczkach z wycieczkami francuskimi. Doszło do nich zapewne w pobliżu twierdzy Hameln, gdzie znajdował się oddział dowodzony przez Werderewskiego — szefa pułku keksholmskiego. Wedle relacji Kamieńskiego 2 stycznia (st. st.) 1806 pułk wyruszył piechotą do Sankt Petersburga.

Tak więc Kamieński był przez cały czas żołnierzem malowanym. Jedyne trudy noszenia oficerskicgo munduru, jakich doświadczył, to burza morska. Daje się tu odczuć wyraźnie Mickiewiczowski klimat Burzy i Żeglugi. Obrazowanie jest podobne: obaj dostrzegają te same elementy żywiołu. Mickiewicz był w pewnym sensie realistą, mimetyczne, przetworzone nicznacznie szczegóły natury sprawiały na nim równie wielkie wrażenie co wywołane przez burzę uczucia. Burza na każdym morzu wygląda podobnie. Kamieński nie miał zamiaru malować morza i tonącego prawic okrętu piórem poety, ale i on nie mógł oprzeć się sile żywiołu, który widział jeden tylko raz. Język opisu morskiej nawałnicy nie jest stylem itinerariuszowego skrótu. Kamieński zatrzymuje się na tym epizodzie długo (porównajmy, ile miejsca poświęca wydarzeniom kluczowym dla przcbiegu działań wojennych w Europie!) i nie używa żołnierskiego ascetycznego stylu. Dziçki sile żywiołu „wzdyma się wyobraźnia” naszego Odyseusza. 
Jest jednak podstawowa różnica w sposobie kreacji bohatera obu utworów: obaj siedzą "na stronie” i przyglądają się innym z oddalenia, jednak ów dystans wynika z czego innego. Mickiewiczowski pielgrzym nie boi się, bowiem jest zrezygnowany. Kamieński natomiast to podróżnik świadomy celu drogi i tego, że podróże kształcą. Siedzi na pokładzie spokojnie i nie poddaje się panice, bowiem jest pewny, że nowy admiralski okręt wytrzyma uderzenie każdej nawałnicy. „(...) w tym zaufaniu usiadłszy na pokładzie, przypatrywałem się cudom natury" - wyznaje. Wrażliwy na piękno natury pragmatyk. Ciekawe, czy Kamieński znał cykl Sonetów krymskich?

Zestawienie sonetów Mickiewicza i tekstu Kamieńskiego, wywołane niewątpliwymi zbieżnościami w obu tekstach, ma jednak charakter bardziej anegdotyczny niż badawczo-filologiczny. Nie ma podstaw, by podejmować się aż tak szczegółowej analizy opowieści dziadka Elizy Orzeszkowej, zwłaszcza że literacka ranga tego tekstu jest mała, natomiast jako dokument osobisty, wycinek literatury pierwszej połowy XIX wieku, itinerarium to jest niewątpliwą ciekawostką. Wiele informacji w tekście sylwy wskazuje, że pisana była w latach trzydziestych, więc lektura dzieła Mickiewicza jest całkiem prawdopodobna.

Obaj autorzy pochodzili z Litwy, dzieliła ich niewielka różnica wieku - obaj mieli zapewne podobną wrażliwość. Jeden nosił carski mundur, drugi polską lutnię. Stosunck obu do rosyjskiego imperium jest do dziś niejasny, podobnie jak wielu Polaków zaplątanych w relacje z Rosją.

\section{Literatura i historia}

Pierwszym obowiązkiem krytyki źródła jest odkrycie intencji piszącego - zabezpiecza to przed szukaniem w tekście czegoś, co nie leżało w jego zamiarach. Intencją Wincentego Kamieńskiego nie były rozważania polityczne, ani też rozdzieranie rosyjskiego munduru, aby ukazać polskie serce. Mamy do czynienia z opisem żołnierskiego marszu.

Do czytelnika zaskakuje ilością przywołanych nazw miejscowych. Można zaryzykować twierdzenie, ze realizuje wiele cech gatunkowych itinerarium ${ }^{3}$ i periegezy ${ }^{4}$. Nie ma tu

\footnotetext{
${ }^{3}$ Itinerarium (łac. iter - droga, podróż) - w piśmiennictwie łacińskim i staropolskim przewodnik dla podróżnych lub opis wędrówki dokonany przez podróżnika czy pielgrzyma, zawierający informacje o przebytych trasach, porady dotyczące miejsc postojów oraz ostrzeżenia przed niebezpieczeństwami, jakie czyhają na wędrowców. Jedno z najważniejszych zachowanych źródeł to Itinerarium Antonini - opis topograficzny głównych dróg lądowych i wodnych Cesarstwa Rzymskiego, powstały zapewne w III wieku n. e. Wcześniej autorem itinerarium był także Horacy (satyra I 5 Egressum magna me accepit Aricia Roma, zwana Iter Brundisinum), który odbył podróż z Rzymu do Brundisium w orszaku Mecenasa. Cel wyprawy był polityczny, lecz Horacy pomija ten aspekt podróży, skupiając się na drobnych wydarzeniach, satyrycznych obserwacjach i praktycznych poradach.

W tradycji liryki staroruskiej istniał gatunek obejmujący relacje z podróży, zwany chożdienija (ros. wędrówki). W chożdienijach opisywano początkowo pielgrzymki do miejsc świętych, później także wędrówki kupieckie. Najciekawszym dziełem tego gatunku jest Wędrólvka za trzy morza Afanasija Nikitina z końca XV w. ${ }^{4}$ Periegeza (gr. periegesis - oprowadzanie, opis geograficzny) - w piśmiennictwie starożytnej Grecji opis podróży mający charakter naukowego sprawozdania lub przewodnika krajoznawczego, zawierającego charakterystyki miejscowości, mieszkańców, zabytków, krajobrazów, wskazówki topograficzne i praktyczne rady dla
} 
oczywiście porad dla podróżnego, gdyż Kamieński szedł z armią i nie zatrzymywał się w przydrożnych karczmach ani (z wyjątkiem opisanego pod koniec tekstu pobytu w Królewcu) w hotelach. Czasu na zwiedzanie zabytków miał mało, ale jeśli takowy posiadał, wykorzystywał go zawsze, by obejrzeć miasto, zamek, stare mury, fabrykę porcelany itp.

Potrzeba utrwalenia wędrówki wzięła się być może z charakteru wykształcenia Kamieńskiego. Przedmowa daje obraz autora wykształconego wedle ówczesnej mody, czyli jak sam przyznaje „wydoskonalonego w języku lacińskim”. Erudycja to być może na skalę gubernialnej szkoły szlacheckiej, dość płytka, ale jednak widoczna. Rozpoczynając swą zabawę piórem, Kamieński powołuje się na Arystarcha, Horacego i Plutarcha jako swych mistrzów. Najbliższym mu antenatem jest niewątpliwie Juliusz Cezar, podobnie jak Kamieński - toute proportion gardée — godzący oręż z piórem. Można przypuszczać, że sławne itineriaria i periegezy również nie były mu obce. Autor wiedział na pewno, że sporządzanie opisu podróży ma wartość nie tylko informacyjną, ale także literacką i że nawet mozolny wojskowy marsz może posłużyć za temat opisu.

Kamieński miał też bliższą tradycję. W wieku XVIII i I połowie XIX nastąpił rozkwit gatunku zwanego dziennikiem podróży ${ }^{5}$. Relacje z wypraw, wycieczek, pielgrzymek, tułaczek przybierały postać dokumentarną i literacką. Bywały faktograficznym sprawozdaniem (często w formie listów) lub powieścią, której akcja rozgrywa się na wyspie Utopii. Nie ma pewności, czy Kamieński sięgał po tego typu literaturę. Jedno jest pewne: studiując prasę, antologie, wypisy, kalendarze, a także czytając współczesną sobie literaturę polską ${ }^{6}$ miał okazję śledzić piśmiennicze mody.

Potrzeba utrwalenia wędrówki z pułkiem keksholmskim mogła wynikać także z bardzo prozaicznego powodu. Owe marsze były jedyną w życiu Kamieńskiego, szlachetki kresowego, okazją zobaczenia świata. Ten fragment Europy, który zapamiętał z lat 1805-1813, stał się przestrzenią uwewnętrznioną przez niego za młodu, co też nie jest bez znaczenia. Wszystko, co przeżyte wcześnie i bujnie, przeradza się potem w legendę i urasta w naszych oczach. Tekst

podróżnika. Najwybitniejsze periegezy opracowali Palemon (II w. p. n. e.) i Pauzaniasz (Wędróuki po Helladzie w 10 księgach, II w. n. e.).

5 Przykładami tego gatunku w literaturze są m.in. Dziennik podróży do Lizbony Henry'ego Fieldinga (1754), Dziennik podróży 1769 roku Johanna Gottfrieda Herdera, Dziennik podróży do Tatrów Seweryna Goszczyńskiego (1832).

${ }^{6}$ Edmund Jankowski, odkrywca i pierwszy komentator wspomnień Kamieńskiego, pisze o zawartości jego sylwy: „Nie zapomniał Kamieński o literaturze pięknej. Widać, że musiał być miłośnikiem poezji. Bardzo często bowiem przytaczał wiersze Ignacego Krasickiego, chyba swego ulubionego poety. Obok potęznej dawki wierszopisarskiego śmiecia wybrał mniejsze czy większe fragmenty prozatorskie i poetyckie z utworów Kazimierza Brodzińskiego, Antoniego Goreckiego, Jana Gorczyczewskiego, Klementyny z Tańskich Hoffmanowej, Jakuba Jasińskiego (...), Franciszka Karpińskiego, Franciszka Dionizego Kniaźnina, Jana Kochanowskiego, Józefa Kossakowskiego, Stanisława Kublickiego, Adama Naruszewicza, Juliana Niemcewicza, Antoniego Edwarda Odyńca, Piotra Skargi, Józefa Szymanowskiego, Szymona Szymonowica, Krystyna Lacha Szyrmy, Stanisława Trembeckiego i Józefa Wybickiego (...), Alojzego Źłłkowskiego i innych. Uderza w tym zestawieniu brak krajana Kamieńskiego, Adama Mickiewicza”. Z pisarzy zagranicznych Kamieński przytacza teksty bajkopisarzy Lokmana, Ezopa i Abstemiusza, a także Horacego, Owidiusza, Senekę, Dzierżawina, Moliera, Rochefoucaulda, Schillera i Woltera (E. Jankowski, op. cit., s. 68). 
Kamieńskiego nie jest przekłamany, zdarzenia nie są opisane przy użyciu hiperboli, brak nieprawdopodobnych wyczynów żołnierskich. Prawie wszystkie marszruty, bitwy, potyczki i wymienione nazwiska udaje się odnaleźć w atlasach, monografiach historycznych i w encyklopediach rosyjskich XIX w. Czasem trzeba poszukać precyzyjniej, bowiem pułk keksholmski jako gwardyjski i wzorcowy trzymano w oddaleniu od głównego teatru wojny poszczególnych kampanii, więc uczestniczył w wydarzeniach, których nie utrwalono w popularnych opracowaniach. Okazuje się, że Kamieński odtworzył prawidłowo przebieg kampanii z lat 1805-1813 (myli jedynie niektóre daty). Opisuje wydarzenia z perspektywy maszerującego wraz ze swym pułkiem oficera. Ważne stają się więc trasy marszu, zapamiętane nazwy miast. Jest ich bardzo dużo, więc brzmienie niektórych na pewno sprawdzał ponownie na mapach, sporządzając po latach historię swej wojaczki. Z pola widzenia niknie wielka polityka, przyczyny i skutki klęsk oraz zwycięstw, warunki porozumień pokojowych itp. Kamieński jawi się jako prosty żołnierz, który przede wszystkim słucha rozkazów (wielokrotnie powtarza „rozkazano nam...”, ,otrzymaliśmy rozkaz...”), a najbardziej interesuje go widok, jaki rozciąga się z końskiego grzbietu (był co prawda w piechocie, ale oficerowie przemieszczali się konno). Nie pojmuje czasu mitycznie, nie szuka sensów przywoływanych wydarzeń, ciąg wspomnień odtwarzany jest linearnie. Ważny staje się każdy powrót do koszar, bo oznacza odpoczynek i wytchnienie od wojennych trudów. Sam Kamieński pisze, iż czas wolny w Petersburgu spędzał przyjemnie: „teatra, bulwary, szpacyjery”, a samo miasto wiele „podziwienia i ukontentowania sprawiło". Przynależność do korpusu oficerskiego elitarnego pułku wiązała się z wieloma przyjemnościami. Młody Polak skłonny był w tej sytuacji zapomnieć o tym, że nie jest Rosjaninem i że walczy za obcą swemu narodowi sprawę. Mundur żołnierski zawładnął całkowicie jego świadomością, przynajmniej tak się wydaje, gdy czytamy tekst Kamieńskiego. Jednak kilka razy w różnych sytuacjach nazywa sicbie Polakiem. Przyznawanie się do polskości nie było dla niego widocznie niczym krępującym. Jego pochodzenie musiało zostać zaakceptowane przez władze pułku, skoro jako Polak (choć w pułku jedyny) został przyjęty do służby. Jedno jest pewne, stosunek Kamieńskiego do Rosji uznać można za bezwzględny lojalizm. Swą świadomość zlał z mundurem, o którym pisze z dumą: „stan rycerski”. Nie widzi nic złego w tym, że jako Polak służy Rosji i że ma wciąż okazję stanąć na polu bitwy twarzą w twarz z rodakiem.

Ostatnio w polskiej historiografii przystapiono do rozbijania utrwalonych w podręcznikach mitów tyczących rusyfikacji i zdecydowanego oporu stawianego jej przez wszystkich Polaków. Andrzej Chwalba w książce o dość prowokacyjnym tytule Polacy w stużbie Moskali przedstawia sytuację panującą w rosyjskiej administracji cywilnej na terenie Królestwa Polskiego po 1863 roku. Autor pisze tu o tych Polakach, którzy mimo akcji odpolaczania podjętej przez władze po powstaniu służyli w rosyjskiej administracji, szkolnictwie, sądownictwie, policji i na kolejach. Stawia wiele ważnych pytań, między innymi takie, które można by zadać Wincentemu Kamieńskiemu, porucznikowi carskiego pulku walczącemu w kampanii antynapoleońskiej, nie tylko przeciw Francuzom, ale także przeciw rodakom: „Czy noszenie 
carskiego munduru współcześni uważali za dowód zdrady narodowej?”, „Na ile postawa wobec munduru (zaborczego) wyznaczała postawę wobec państwa (zaborczego)?”, "Jakie były źródła marzeń tak wielu o czapce służbowej i mundurze?” Chwalba powtarza wielokrotnie opinię wypowiedzianą przez Stefana Kieniewicza o powstaniu 1863 roku jako walce bratobójczej, noszącej znamiona wojny domowej ${ }^{8}$. Istnienie polskich grup zbrojnych prowadzących walkę z powstańcami, wiernopoddańcze adresy kierowane do cara - a wszystko to w przekonaniu, iż ratuje się dzieło reform margrabiego Wielopolskiego.

Autor przekonuje, iż praca w sądownictwie czy na kolei niekoniecznie musiała być synonimem zdrady narodowej. Częściej bywała koniecznością ekonomiczną, walczono nie o sam rosyjski mundur służb cywilnych, który dla Polaka niczego właściwie nie symbolizował, ale o pensję z nim związaną. Polacy zatrudnieni na przykład na kolei rzadko musieli dokonywać kompromisu z własną patriotyczną postawą, ponieważ nikt tego od nich nie wymagał.

Inaczej ma się sprawa z naszym bohaterem. Wincenty Kamieński walczył w armii rosyjskiej. Niemożliwe, by nie zdawał sobie sprawy z nadziei, jakie Polacy wiążą z osobą Napoleona. Musiał więc stać po stronie rosyjskiej racji stanu także w kwestii polskiej.

Autor Polaków w slużbie Moskali rozpatruje przywdziewanie przez naszych rodaków moskiewskich mundurów także jako swoisty akt patriotyzmu:

(...) patriotyczna argumentacja uzasadniająca zachowanie posad $\mathrm{w}$ «polskich rękach» [po 1864 r. - I. W.] może razić, może nawet irytować, niemniej nie możemy jej uznawać za zupełnie bezzasadną we wszystkich sytuacjach, zwłaszcza, żc sens słowa patriotyzm uległ przewartościowaniu. Dawniej oznaczał aktywną postawę w powstaniach, udział w spiskach i konspiracji, jawny sprzeciw wobec polityki zaborców. Po roku 1864 patriotyzm wyrażał się w rozumnych działaniach organicznikowskich, w pracy na rzecz oświaty ludu wiejskiego, działaniach na korzyść postępu cywilizacyjnego i lokalnych swobód, wreszcie w staraniach o zachowanie posad rządowych. Następstwem tego ostatniego było nagminne utożsamianie osobistych karier z pożytkiem ojczyzny 9 .

„Gdzie kariera, tam ojczyzna”? Ta nowa formuła patriotyzmu charakterystyczna dla czasów popowstaniowych przewartościowuje nasze myślenie o epoce, zwłaszcza że tezę te potwierdzają liczby. Twórcami mitu depolonizacji przeprowadzanej rękami Rosjan byli sami Polacy, świadkowie epoki, którzy nie chcieli dostrzegać Polaków w rosyjskich mundurach. Literatura udawała więc nie tylko, że nie ma Rosjan, ale nie dostrzegała też problemu, jakim byli Polacy, nie renegaci przecież, a po prostu tacy, którzy pracowali jako wojskowi lekarze, nauczyciele, urzędnicy pocztowi czy kolejarze. Nikt nie traktował ich jako zaprzańców.

\footnotetext{
${ }^{7}$ A. Chwalba, Polacy $w$ stużbie Moskali, Warszawa-Kraków 1999, s. 7.

${ }^{8}$ S. Kieniewicz, Pou'stanie styczniouve, Warszawa 1972.

9 A. Chwalba, op. cit., s. 54.
} 
Zapotrzebowanie na heroiczny wizerunek dziejów narodu polskiego, wizerunek nie dopuszczający odszczepieńców, było tak silne, że mit przetrwał. Jednak fakty, czyli dokumenty archiwalne są bezlitosne - obnażają jednowymiarowość mitu i każą zastanowić się nad nowym wizerunkiem polskości w XIX wieku. Przytoczmy jeszcze jeden cytat z książki Andrzeja Chwalby, który jest argumentem potwierdzającym tezę o akceptacji rosyjskiego munduru przez społeczeństwo polskie:

(...) w niepodległej Polsce nadal na urzędach znajdowały się osoby, które sądziły, skazywały, więziły polskich patriotów. Agenci ochrany i policji, carscy urzędnicy zasłużeni w polityce unifikacyjnej, otrzymali w czasach II Rzeczypospolitej wysokie pensje, a następnie emerytury, gdy ich ofiary niejednokrotnie żyły i umierały w niedostatku. (...) Brak lustracji dowodził, iż niepodległa Polska (i jej mieszkańcy), tak bardzo ceniąca sobie wartości narodowe i patriotyczne, nie potrafiła, a w rzeczywistości nie chciała osądzić i zweryfikować postaw tych wszystkich, którzy lojalnie służyli zaborcom i realizowali ich politykę ${ }^{10}$.

Problem lustracji do dziś dzieli polskie społeczeństwo - tym razem tyczy tych, którzy współpracowali ze służbami bezpieczeństwa PRL-u, a więc działali na rzecz Rosji. Stawia się pytania o to, czy istnieje niezależna od warunków historycznych racja stanu, czy warunki życia nie moga zmienić świadomości obywatela, co to znaczy służyć obcemu mocarstwu? Czy nauczyciel pracujący w szkole peerelowskiej i nauczający wedle programu zatwierdzonego przez ówczesnych decydentów działał na szkodę polskiej racji stanu, czy tylko zarabiał na życie? Przecież zmieniał świadomość młodego pokolenia zgodnie z zaleceniami sowieckiej centrali! Te same pytania postawić możemy polskiej kadrze cywilnej administracji Królestwa Polskiego i tak zwanych guberni zachodnich cesarstwa rosyjskiego.

Ofiarą mitu, który ściśle wyznaczał granicę między Rosjanami-ciemiężycielami i Polakami-ciemiężonymi, padła wnuczka bohatera niniejszego tekstu, Eliza Orzeszkowa. Od 1864 roku przyświecał jej ewangeliczno-organicznikowski ideał „miłość i praca”. Wyrzeczenie równało się samorealizacji. Zasłużyć na miano człowieka można wtedy, gdy zrezygnujemy $z$ własnych potrzeb w imię ideałów. Pryzmatem Orzeszkowej była zbiorowość: społeczeństwo i naród. Wszyscy jej bohaterowie realizują się w ten sposób, jaki ona uznała za pełnię człowieczeństwa. Jednak fakty czasem nie dają się nagiąć do poziomu ideału — wtedy trzeba mijać się z prawdą lub przemilczać. Taka potrzeba stanęła przed Elizą. W Pamiętniku (nigdy nie ukończonym) pisanym na prośbę warszawskiego przyjaciela, Leopolda Méyeta ${ }^{11}$, Orzeszkowa nadaje swemu macierzystemu dziadkowi, Wincentemu Kamieńskiemu, godność oficera wojsk napoleońskich. Nie chcę tu odtwarzać historii zmagań biografów Elizy z tym

10 Tamże, s. 244.

" Pierwodruk w „Kurierze Warszawskim” 1911, nry 24-39, calość poprzedzona słowem wstępnym Méyeta. 
fragmentem jej genealogii, gdyż zrobił to dokładnie wiele lat temu w cytowanym artykule prof. Edmund Jankowski. Jak wiemy, informacja ta jest całkowicie zmyślona. Dlaczego Orzeszkowa przekłamała tak ważny szczegół swej genealogii? Czemu służyć miała owa napoleońska tradycja? Czy tylko ukryciu faktu, że Kamieński wysługiwał się z dobrą wolą zaborcy? Zapewne fakt ten byłby w czasach postyczniowych komentowany niezbyt pochlebnie dla autorki Nad Niemnem. Nikt przez lat kilkadziesiąt nie zorientował się w napoleońskiej mistyfikacji Orzeszkowej. Jankowski wysuwa następującą hipotezę:

Dziadek-napoleończyk wypłynął w biografii Orzeszkowej dopiero w okresie jubileuszu [chodzi o rok 1891, kiedy to Eliza dostarczyła Piotrowi Chmielowskiemu materiały, na podstawie których sporządził spory szkic mający stanowić jeden z wielu hołdów złożonych jubilatce z okazji 25-lecia debiutu - I. W.] Musimy jeszcze pobawić się w rozważania psychologiczno-moralne. Czy podobna przypuścić, aby człowiek o takiej wrażliwości moralnej jak Orzeszkowa i o takiej jak ona odpowiedzialności za słowo dopuszczał się świadomie przeinaczenia prawdy? (...) Tylko naiwna biografistyka mogła utwierdzać w przekonaniu, że tzw. człowiek wielki wraz z talentem otrzymuje patent na dożywotnią doskonałość. Nie dowierzali temu najwięksi pisarze i moraliści wszystkich czasów. (...) gdy dziś w sposób krytyczny - a nie wyznawczy - wczytujemy się na przykład w listy Orzeszkowej, przychwytujemy pisarkę niekiedy na niedopowiedzeniach, na nieścisłościach, na odkształceniach prawdy.

Jankowski nazywa Elizę „błądzącą, lecz wysiloną ku dobremu”12.

Tak więc dopiero w roku 1891, kiedy to Eliza szykowała się do wielkiego, na jej cześć organizowanego święta polskiego światka literackiego, zaczęła dopisywać swej rodzinie tradycje narodowowyzwoleńcze. Oczywiście, można przyjmować argument, że najważniejsza była tu dobra wola jubilatki, owo „wysilenie ku dobremu”. Wszyscy wiemy wszak doskonale, że Pan Tadeusz i tradycja legionowa była najpowszechniej wtedy przyjmowaną prawdą ojczyźnianą. Eliza była przekonana, że społeczeństwo polskie będzie od niej wymagać świadectw polskości, skoro ona wymagała ich od bohaterów swych książek, kreując się na maksymalistkę w sprawach narodowej wiary. Takie świadectwo więc mu dała, a był nim mimochodem jakby wspomniany dziad-napoleończyk. Był to jeden z pierwszych kroków Orzeszkowej w podjętym przez nią projekcie biografii idealnej. Niechęć wobec wojska zaborcy podkreślała mocno nawet w swym grodzieńskim otoczeniu:

Do zwyczajów Orzeszkowej należało, że nie przyjmowała w swoim domu Polaków pełniących służbę zawodowych oficerów w armii rosyjskiej. Z tego też powodu były całe tragedie przy wyjściu za mąż za takich oficerów kilku dawnych uczennic pisarki: Pauliny Godlewskiej, Józefy Bagieńskiej i jej siostry

12 E. Jankowski, op. cit., s. 78-79. 
Zofii. Mężowie ich zresztą nigdy nie bywali u Orzeszkowej, nawet po pogodzeniu się Orzeszkowej z ich żonami ${ }^{13}$.

Tu warto jednak zaznaczyć, że jakkolwiek Orzeszkowa nie przyjmowała u siebie męża Pauliny Godlewskiej, Emanuela Bokszczanina, to jednak przed bratem Pauliny, Franciszkiem Godlewskim, drzwi „szarego domku” zawsze stały otworem. A przecież Godlewski był oficerem stacjonującego w Grodnie sto pierwszego pułku piechoty. Po śmierci drugiego męża Elizy, Godlewski stał się obiektem skrywanych uczuć pisarki. Był jednak przyjmowany dużo wcześniej, jeszcze za życia Stanisława Nahorskiego. W świetle powyższych faktów osobisty stosunek Orzeszkowej do Polaków w armii rosyjskiej nie wydaje się tak dogmatyczny. Inaczej sprawa przedstawia się w jej tekstach.

W 1910 roku księgarnia nakładowa Wacława Makowskiego z Wilna opublikowała ostatni tom opowiadań Orzeszkowej Gloria victis. Jest to ciąg utworów, w których więcej jest prawdy niż fikcji. Autorka przechowywała wspomnienia z 1863 roku przez długi czas. Przeżycie wiosny, lata i jesieni 1863 roku, potem okresu śledztw i represji, było życiową traumą Orzeszkowej. Sama uczestniczyła aktywnie w wydarzeniach na Kobryńszczyźnie, przewoziła powstańczą pocztę, gościła w Ludwinowie kurierów, ukrywała przez jakiś czas Romualda Traugutta. Pole bitwy widziała raz jeden - nazajutrz o poranku, gdy uprzątano jedną z polanek w lasach horeckich: ludzkie i końskie trupy w męczeńskich postawach pojawią się później w Gloria victis i w Oficerze. Po klęsce dwudziestokilkuletnia młoda mężatka przeżywa odejście całego swego dotychczasowego świata. Większość sąsiadów, znajomych (także kobiet), a przede wszystkim mąż pisarki zostają aresztowani ${ }^{14}$ lub emigrują z Litwy. Po ukończeniu śledztwa w sprawie Piotra Orzeszki (zesłano go do guberni permskiej), Eliza wyjeżdża do swego poojcowskiego majątku — do Milkowszczyzny. Ludwinów zostaje wystawiony na przymusową sprzedaż.

Przez ponad czterdzieści lat powstanie styczniowe pojawia się w twórczości Orzeszkowej jedynie w refleksach przybranych w symboliczny kostium ze względu na cenzurę. Dopiero po rewolucji 1905 Orzeszkowa decyduje się powrócić do swego pokoleniowego przeżycia.

\footnotetext{
${ }^{13}$ M. Wyganowska-Gieroyciowa, Wspomnienia, s. 59. Jest to tekst niedrukowany. Maszynopis udostępniony przez rodzinę autorki, która także była jedną z grodzieńskich wychowanek Orzeszkowej.

${ }_{14}$ Sprawa Piotra Orzeszki jest dwuznaczna i zakrawa na ironię losu. W przeciwieństwie do swych braci, nie uczestniczył on bowiem zbrojnie w powstaniu, co więcej, nawet nie był jego entuzjastą. Jednak zostaje aresztowany, gdyż to właśnie $\mathrm{w}$ dworze Orzeszków, Ludwinowie, ukrywał się Traugutt, zatrzymywali się powstańczy kurierzy. W newralgicznych momentach Piotr wyjeżdżał do Kobrynia, niby na targ, bądź w sprawach majątku, lecz głównie po to, by nie być blisko tego, co się w Ludwinowie działo. O wszystkim tym doniósł władzom jeden z ludwinowskich służących. Nazwisko Orzeszkowej pojawia się bardzo dyskretnie w aktach śledztwa. Być może sprawa udziału Elizy została wyciszona łapówką, gdyż niemożliwe jest, by pani na Ludwinowie została pominięta w obciązających całą rodzinę Orzeszków zeznaniach stangreta. Aresztowanie Piotra nie było dla Elizy większą tragedią niż strata okolicznych przyjaciół i krewnych. Nie udało się jej znaleźć w mężu odpowiedniego partnera ani zbudować szczęśliwych związków rodzinnych. Jeszcze przed powstaniem podejmuje decyzję o odejściu od małżonka, wyjeżdża do matki, która jednak odsyła dziewczynę z powrotem. Powstanie jedynie opóźnia decyzję o rozstaniu. Brak uczucia dla męża nie pozwala jej jechać za nim na wygnanie do Permu.
} 
W jej liście do Aurelego Drogoszewskiego z kwietnia 1907 r. czytamy o wydarzeniach powstania w kobryńskiem:

Nigdy zupełnie nie traciłam ich z pamięci, z myśli pełnej czci, z serca pełnego żałości. Ale wiedziałam, że zajmować się nimi daremnie; głośno opowiadać ich było nie wolno. Teraz wolno, więc zupełnie samoistnie, bez żadnych moich starań ani wysileń wskrzesły w pełnych barwach i kształtach. Są tam rzeczy, o których jeżeli ja nie opowiem, nikt nigdy wiedzieć nie będzie, bo wszyscy prawie współcześni już wymarli, nic głośno nie opowiedziawszy. Jednak potężnym w nich jest pierwiastek dramatyczny i dla pokoleń najmłodszych, za mało może zajmujących się przeszłością, więc za mało ją znających, niejedna może nicznana czy zapoznana prawda ${ }^{15}$.

W cyklu Gloria victis jako kontekst dla problemów związanych z Wincentym Kamieńskim istotne jest opowiadanie Oficer. Powiela ono sytuację dziadka Orzeszkowej, choć już w innych realiach historycznych - Polak przywdziewa rosyjski mundur i walczy przeciw rodakom tłumiąc powstanie 1863. Tytułowy oficer, Apolinary Karłowicki, nie wstąpił do wojska dla kariery. Do korpusu kadetów oddał go ojciec, gdy chłopak miał lat jedenaście. Rodzic także nic miał wielkiego wyboru, sam bankrut i pijak, zadbał jak najlepiej potrafił o przyszłość chłopca. Jednak mistyka munduru zawładnęła Karłowickim — polubił służbę w wojsku i zapomniał nawet nieco polskiej mowy. Twarzą w twarz ze swą polskością staje dopiero w roku 1863, gdy pewnego dnia na Polesiu litewskim dowodzony przez niego oddział bije się z powstańcami. W czasie walki Karłowicki rozpoznaje wśród zabitych swego stryjecznego brata, noszącego to samo nazwisko ${ }^{16}$ :

${ }^{15}$ Eliza Orzeszkowa do Aurelego Drogoszewskiego, list z 8 [21] kwietnia 1907 [w:] E. Orzeszkowa, Listy zebrane, oprac. E. Jankowski, t. IV, Wrocław 1958, s. 211.

${ }_{16}$ Wiçkszość wydarzeń utrwalonych w cyklu Gloria victis ma podłoże historyczne i związana jest ze zdarzenjami prawdziwymi. I tak na przykład Orzeszkowa była świadkiem obejmowania przez Romualda Traugutta dowództwa nad partią kobryńską w majątku Bożydar należącym do Jana Mitraszewskiego, naczelnika miasta Kobryń z ramienia Rządu Narodowego. Zdarzenie miało miejsce 26 kwietnia 1863 r. (patrz opowiadanie Oni). W opowiadaniu Gloria victis opisuje bitwę, której pobojowisko zwiedzała nazajutrz: „Bitwy co prawda na własne oczy nie widziałam żadnej, ale jedną słyszałam we dworze jednego z Orzeszków, o niecała wiorstę oddalonym od miejsca, w którym się toczyła. Było to po drugiej stronie Kanału Królewieckiego, w lasach tzw. Horeckich. Zwiedziłam potem miejsce, na którym się stoczyła, i widziałam pustą polanę, na której partia przez trzy tygodnie obozowała. Jeszcze leżały tam niepogrzebane trupy końskie, stały namioty z gałęzi splecione i już wznosił się kopiec ze zwłokami poległych powstańców." (E. Orzeszkowa do M. Dubieckiego, list z 6 lutego 1907, Grodno, [w:] E. Orzeszkowa, Listy zebrane, op. cit., s. 243).

Niektóre z wydarzeń opisanych w powstańczym cyklu należą do opowieści, których wiele krążyło na Kobryńszczyźnie. Nie wszystkie są dziś możliwe do zweryfikowania. Jedną z owych klechd zdaje się być historia opowiedziana w Oficerze. Pojawia się tu nazwisko Apolinarego Karłowickiego - nosi je zarówno poległy powstaniec, jak i rosyjski oficer, krewny zabitego. Karlowicki jest zapewne fabularnym nazwiskiem postaci autentycznej, Apolinarego Radowickiego, dziedzica majątku Dziatkowicze. 17 maja 1863 r. powstańcy roznieśli na grobli w lasach Horeckich rotę piechoty moskiewskiej jadącą na furmankach, osłanianą przez 15 kozaków. Po dojściu wiadomości do Kobrynia, Rosjanie wysłali na odsiecz dwie roty strzelców dowodzone przez pulkownika Ehrnberga. W stoczonej 21 maja bitwie pod Horkami (gub. grodzieńska, pow. kobryński) poległ Apolinary Radowicki. Inny Radowicki, Gustaw, także sąsiad i dobry znajomy Elizy i Piotra Orzeszków, 
Idziesz z wojskiem na miatieżnikow i głaz na głaz spotykasz się z bratem... z bratem, którego jak swoje życie lubisz. I twego brata zabija to wojsko, któremu ty sam zakomenderował: strzelać! ${ }^{17}$

- mówi przerażony sytuacją Karłowicki.

Czy Wincenty Kamieński stanął kiedykolwiek oko w oko z polskimi oddziałami? Teoretycznie miał kilka takich okazji. Jednak żadne refleksy takich sytuacji nie pojawiają się w jego tekście. Być może Orzeszkowa pisząc Oficera miała także w pamięci historię swego przodka, która pozostawała ukryta w jednej z grubych ksiag jej biblioteki. Być może dlatego wybrała tę właśnie klechdę spośród dziesiątek innych, które tyczyły powstania na Polesiu, i uczyniła postać rosyjskiego oficera tak ludzką i tragiczną. W treści opowiadania nie ma męczącej patetyki, jest jedynie sytuacja tragiczna. Natomiast wprowadzenie do utworu to proza poetycka, która jednocześnie przypomina czytelnikom mity, wedle których należy odczytywać opowieść. Oto propozycja Orzeszkowej:

Niech serca ostygające dla ojczyzny przybliżą się do tego żużla, który niegdyś spadł był na jej drogę, niech odetchną wonią jego piekącą i gorzką.

To woń samego miąższu drzewa spalonego na ofiarnym stosie. Kto ją w płuca swe wciąga, tego oczy napełnią się łzami i serce uderzy mocno, a w tych łzach i w tym uderzeniu wskrześnie Miłość.

(...)

Ta, której zakochane oczy obejmują ziemię ojczystą, jak nad wszystko w świecie rodzeńsze, milsze oblicze matki;

której przywiązane oczy wpatrują się w naród ojczysty, jak w nad wszystkie inne bliższe, milsze grono rodzonych braci;

której wierne oczy towarzyszą braciom na drogach cnót, nad którymi rozpalają pochodnie radości;

której uwielbiające oczy wznoszą się ku dwom wielkim gwiazdom, noszącym imiona Sprawiedliwość i Wolność;

której mądre oczy dostrzegają, że bez światła tych dwóch gwiazd ciemna musi być ziemia i nieszczęśliwymi muszą być jej narody.

Oto stylistyka budująca pewien paradygmat widzenia spraw ojczyźnianych. Stos ofiarny i opłakująca swe dzieci ojczyzna-matka to model ewangelicznej matki cierpiącej pod krzy-

adiutant Traugutta, został aresztowany 29 maja 1863. Osadzono go w kobryńskim więzieniu i oskarżono o przestępstwa polityczne. Obaj Radowiccy zdają się być pierwowzorami poległego Karłowickiego i pochwyconego w lesie Olesia Awicza. Nie wiadomo jednak, kto mógłby być pierwowzorem postaci kapitana Karłowickiego. Kapitan Kiersnowski, Polak z pochodzenia, który dowodził oddziałem piechoty podczas jednej z pierwszych bitew Traugutta w lasach horeckich, poległ 17 maja. Był znany z rozbojów i łotrostwa, Rząd Narodowy wydał nań wyrok śmierci. Być może to właśnie z jego postacią była związana legenda o wyrzutach sumienia z powodu noszenia rosyjskiego munduru.

${ }_{17}$ Wszystkie cytaty z Gloria victis pochodzą z wydania: E. Orzeszkowa, Pisma, red. J. Krzyżanowski, t. XXXVI, Warszawa 1951. 
żcm. Nie ma tu miejsca na dyskusje o tym, co znaczy być Polakiem. Prawdziwymi synami ojczyzny są tylko ci, których się właśnie opłakuje, oni weszli do mitycznej, ponadhistorycznej historii Polski. Orzeszkowa ożywia mit powstańczy, psychizuje czas narracji — narratorka każdego z tekstów Gloria victis to naoczny świadek wydarzeń, które wciąż rozgrywają się przed jej oczami, „powstają tętniące pulsem chwili”. Jak na tle tak emocjonalnego stosunku do historii ${ }^{18}$ wypaść może Polak ubrany w rosyjski mundur? Musi zostać postawiony w sytuacji tragicznego wyboru pomiędzy wiernością ojczyźnie przodków a wiernością honorowi rosyjskiego oficera. Karłowicki ratuje od śmierci aresztowanego w lesie Aleksandra Awicza, kolegę swego poległego brata. Umożliwia mu ucieczkę zdradzając rosyjską władzę i znieważając mundur, który jej służy. Oszukuje także swego przyjaciela, rosyjskiego dygnitarza, który ułatwia mu widzenia z Awiczem, myśląc, że kapitan chce przekonać młodego Polaka do zmiany zeznań. Karłowicki wybrał: ratując życie powstańca, zerwał automatycznic więzy łączące go z dotychczasowym życiem, ale zerwał je tylko zewnętrznie. W jego wnętrzu bowiem wciąż nie ma zgody na tak jednoznaczny wybór. Karłowicki był Wallenrodem tylko przez moment. Gdy należało już jawnie być Polakiem, zrzucić mundur rosyjski i uciekać z Awiczem, on odmówił. Został i popełnił samobójstwo. Czy dlatego, że „nie umiał wybrać między polskością i rosyjskością"? ${ }^{19}$ Raczej nie, bowiem wyboru przynależności narodowej dokonał jeszcze przed uwolnieniem Awicza. To ów wybór zmusił go do zwrotu daniny, którą winien był ojczyźnie. W opowiadaniu znajdujemy wiele fragmentów, które mówią, że w Karłowickim dokonuje się przebudzenie ducha narodu, którego można jedynie uśpić, zaś usunąć na dobre ze swego wnętrza nie można. Narrator prowadzi bohatera bardzo delikatnie ku polskości. Najpierw budzą się w nim uczucia związane z rodziną, gdy przerażony patrzy na zwłoki zabitego przed chwilą brata. Decyzja o odwiedzinach w celi Awicza zapada poza oczami czytelnika, kolejne etapy przemian możemy śledzić podczas rozmów, które Karłowicki prowadzi z młodym powstańcem. Opowieści o poległym bracie i rodzinic stopniowo przeradzają się w głębszy dialog. Gdy oficer mówi o swym polskim pochodzeniu, wyznaje:

\footnotetext{
${ }^{18}$ Owe emocje związane z wydarzeniami lat 1863-1864 opisuje Orzeszkowa w jednym ze swych tekstów autobiograficznych: „Stałam się dwudziestoletnim świadkiem jednej z katastrof społecznych, najokropniejszych, jakie dostępnymi być mogą oczom śmiertelnych. Widziałam domy ludne i gwarne wymiecione z ludzi, jak w średniowieczne mory, wielkie mogiły wznoszące się wśród lasów, kryjące tych, z którymi niedawno tańczyłam, nawiedzane tylko przez leśnych ptaków; widziałam szubienice rysujące na niebie suche profile, blade strachy idącyclı na śmierć, konające nadzieje, krwawe bóle, ponure żałoby, orszaki więźniów dzwoniących łańcuchami w drodze na Sybir, $z$ długimi za sobą orszakami rodzin osieroconych i wtrąconych w nędzę. Słyszałam odgłosy bitew staczanych w wielkich lasach poleskich, wieści dochodzące $z$ dala o zbiorowych śmierciach, spadających nie na setki, lecz na tysiące ludzi po etapach sybirskich, od chłodu, nędzy, ścisku, zarazy... Widziałam ustawy prawne, jawne i tajemne (przed Europą tajone), które jak grad gęsty spadały na nas, odsądzając nas od posiadania ziemi, prawa do pracy, zarobku, zasługi, mówienia własnym językiem, uczenia dzieci naszych wiary i historii przodków w języku przodków." (Autobiografia, [w:] E. Orzeszkowa, O sobie, Warszawa 1974, s. 102).

${ }_{19}$ Tak interpretuje opowiadanie Grażyna Borkowska, zob. taż, Pozytrniśsi i inni, Warszawa 1996, s. 108.
} 
(...) ja, nim tu $z$ wojskiem przyjechał, nigdy o takich rzeczach nie myślał. Nie przywykł. A jeżeli kiedy i pomyślał, to zawsze tylko tyle, że takie rzeczy potno niczewo nie znaczą. I teraz dopiero ja zaczął o nich myśleć... i zaczęło mnic zdawać się, że one coś znaczą.

Trudno mu pogodzić się z tym, co robi na Polesiu jako rosyjski oficer:

I najgorsze to, że czlowiek sam siebie nie rozumie i czasem sam na siebie chciałby plunąć... To i nie chce się czasem po tym świecie chodzić.

Jednocześnie uważa, że powinien służyć uczciwie, skoro poszedł na służbę. Inaczej byłby zdrajcą, „a zdrada to paskudna, brudna rzecz”.

Karłowicki początkowo nie rozumie odzywających się w nim „instynktów”. Są one jednak nie do pokonania. Gdy ocalona przez niego polska rodzina prosi go o podanie nazwiska, ten odmawia. Wstydzi się jego polskiego brzmienia w parze z rosyjskim mundurem. Jest to jeden z najbardziej wymownych punktów opowiadania. Wedle Orzeszkowej polskość jest czymś organicznym, niczym determinanta genetyczna, która ma szansę odezwać się w każdym momencie naszego życia, wystarczą tylko odpowiednie warunki do jej wywołania. Karłowicki, do jedenastego roku życia wychowywany w polskiej rodzinie, zruszczył się potem całkowicie w pułku, jednak przeżycia z dzieciństwa ożywały zawsze wtedy, gdy pojawiało się coś z ojczyzną związanego: brat studiujący w Petersburgu czy służba na Polesiu w oddziałach tłumiących ruch partyzancki. Dręczące sny Karłowickiego, w których udowadnia swemu zastrzelonemu bratu, że powstanie to „bezumje jest - sumaszestwie naprzcciw takiej potęgi stawać...", prowadzą go jednak do rozwiązania zagadki swych koszmarów. Wyznaje Awiczowi: „I wy wszyscy moja krew, ja to poczuł teraz, kiedy was poznał...”. Karłowicki jest już więc Polakiem. Pytanie: dlaczego nie chciał radykalnie rozwiązać problemu rosyjskiego munduru? Wystarczyło zrzucić go w odpowiednim momencie, a przecież taki się nadarzył. Wydawałoby się, że swym czynem odkupił służbę zaborcy.

Sytuacja wykreowana przez Orzeszkową należała do dość często spotykanych w tamtych czasach. Robienie karier w armii zaborcy było po prostu jednym ze sposobów na życie. Przypomnijmy chociażby sylwetkę Romualda Traugutta, który doszedł do stopnia podpulkownika saperów w wojsku rosyjskim. Poprosił o dymisję w 1860 roku. Nie wiadomo jednak, jakie dylematy zrodzić by się w nim mogły, gdyby w czasie wybuchu powstania w Kobryńskiem pozostawał w słuzbie czynnej. Karłowicki był pełen poszanowania i czci dla potęgi armii rosyjskiej, której cząstkę sam stanowił. Chce jednak za wszelką cenę zrozumieć, co popchnęło "garść ludzi niewojentıych" do wystąpienia przeciw niezwyciężonemu dwugłowemu orłu. Awicz odkrywa przed Karłowickim coś, co jak się zdaje było najbliższe myśli politycznej samej Orzeszkowej - świat idei. Odradzająca się w kolejnych pokoleniach myśl narodowowyzwoleńcza podobna jest do archetypu właściwego wyłącznie polskiej nieświadomości zbiorowej: 
Dziś pociskami armatnimi na proch starta idea odrodzi się jutro, i jej być musi prędzej czy później zwycięstwo ostateczne, i ona jest rozumem wyższym nad cyfrę twojej armii, nad twoje petersburskie granity i malachity, nad twoje szyderstwa i gniewy — bo jest samą prawdą świata i Boga

- argumentuje Oleś Awicz. Po stronie tego pozarozumowego i poza argumentami z kręgu cyfr i logiki stojącego mitu eleuzyjskiego opowiada się Orzeszkowa. Nigdy nie zrozumiałaby swego dziadka, Wincentego Kamieńskiego, który dał się uwieść rosyjskiemu mitowi: wierze w potęgę armii samodzierżawcy ${ }^{20}$.

Po rozmowie z Olesiem, zarażony ideą Karłowicki nazywa siebie człowiekiem zgubionym i przestaje wierzyć w sens swej służby: „choćby i jenerałem został, to czuję!... że adnakoż zgubiony!".

Jednak nie seria rozmów Karłowickiego z Awiczem w celi więziennej zdaje się być najważniejszym fragmentem opowiadania. Jest nim niewątpliwie ostatnia scena: samobójstwo głównego bohatera, który umiera samotnie, darowawszy wprzódy wolność Awiczowi. Co oznacza wybór Karłowickiego? Decyzję tę można rozpatrywać jedynie na płaszczyźnie egzystencjalnej, poza podziałami narodowościowymi. W każdym razie jest to niewątpliwie ucieczka. Postanowienie o wycofaniu się z życia przyniosło Karłowickiemu nieoczekiwany spokój ducha, nieznaną dotąd harmonię. Decyzję o ratowaniu Awicza i samobójstwie podejmuje po samotnym, całodziennym dumaniu w lesie. „Czy to samotność i natura tchnęły w niego spokój i ukojenie? Bo rysy miał ukojone, kark wyprostowany i krok spokojny, równy" - pyta dyskretny narrator.

Czy „ucieczka” Karłowickiego akceptowana jest przez Orzeszkową? Na trop prawdopodobnych sądów autora naprowadza przytoczony wyżej fragment prozy poetyckiej, rysujący schemat ojczyźnianego mitu, w którym nie ma miejsca na wallenrodyzm ani rezygnację. Jest jeden słuszny wybór, którego należy dokonać. Jakże tragicznie rysuje się w kontekście owego mitu postawa Karłowickiego i jego dylematy. Pomimo oficerskich szlifów jest człowiekiem o wielkiej prostocie ducha, niewiele pojmuje z tego, co czuje. Gdy rozumie, jak dziwna jest jego sytuacja, wybiera śmierć. Być może konstrukcja artystyczna Oficera zakładała ten właśnie rozdźwięk: niemożność wypełnienia każdego życia jednym mitem i jedną prawdą. Jest to sytuacja uniwersalna, swego rodzaju projekt egzystencjalny. Bohaterów antycznych tragedii los karał za grzechy przodków. Sytuacja Karłowickiego jest podobna: został wystawiony na hiobową próbę, ponieważ jego ojciec nie miał pieniędzy na kształcenie chłopca i oddał go armii zaborcy. Taki sens zdaje się mieć przytoczenie w opowiadaniu retrospektywnego fragmentu biografii tej postaci. Każdy z bohaterów antycznych tragedii sam wymierza sobie

\footnotetext{
${ }^{20}$ Myślenie mityczne, tak charakterystyczne dla dziewiętnastowiecznego sposobu poznania, obejmowało także sferę historii i polityki. W drugiej połowie XIX wieku upowszechnia się powoli przekonanie, że mit to najpierwotniejsza forma poznania i jeden z języków artykulacji świata. Mówiąc o mitycznym myśleniu Orzeszkowej i fascynacjach jej dziadka, mam na myśli mit będący próbą uporządkowania faktów ogólnych, pewnych tendencji dostrzeganych w świadomości zbiorowej tych czasów.
} 
karę, wyprzedzając fatum, czyli działanie wyroku wydanego przez otoczenie. Karłowicki, podobny Edypowi wykłuwającemu sobie oczy, strzela do siebie ze swego oficerskiego rewolweru. Nie chce, by sądzili go inni.

(...) kiedy człowiek popełnia na przykład samobójstwo, rozstaje się z życiem jedynie z tej racji, by się ratować, żeby się pozbyć czegoś niewygodnego; nie znaczy to, by nie chciał samego siebie: nie chce brzemienia, które nosi ${ }^{21}$.

Jak owo brzemię oddzielić od ciała, nośnika wszelkich sensualnych i duchowych atrybutów naszej egzystencji? Niemożliwe. Unicestwiamy więc siebie. Współczesna psychoanaliza dostarcza wielu sposobów na zrzucenie brzemienia. Czy jednak wyartykułowanie problemu i zrozumienie przyczyn bólu łagodzi go? Karłowicki po swoistym seansie psychoanalitycznym w celi Awicza zrozumiał przyczynę swych cierpień. Mimo to na dalsze życie z ową wiedzą nie chciał się zdecydować. Narrator, który dotąd pozostawiał czytelnika sam na sam z cierpieniami bohatera i nie ujawniał swej wszechwiedzy, na końcu zawiesza swą dyskrecję i odzywa się pełnym współczucia dla swej postaci głosem:

Ej, krwi od rodu ojczystego w dziedzictwie otrzymana, jak ty czasem obojętnie w żyłach człowieczych krążysz, aż wzburzysz się i zapłoniesz zgryzotą śmiertelną!

$\mathrm{Ej}$, ty niewolniku biedny, któremu palce ugniotły duszę w kształt dla niego pożądany, coś uczynił, gdy ta dusza ocknęła się i krzyknęła, że taką pragnie zostać, jaką stworzył ją Pan Niebieski?

Orzeszkowa mówi tu o poczuciu przynależności narodowej nie tylko jako o właściwości dziedzicznej, ale przede wszystkim nadaje mu cechy sacrum. Bycie Polakiem czy Rosjaninem to atrybut Boga w każdym człowieku, boski wybór. Decyzja o zmianie narodowości musi zostać ukarana, bowiem jest to wystąpienie przeciw boskiemu porządkowi egzystencji. A więc jesteśmy ponad historią, poza dziejami. Maska roku 1863 zdaje się ukazywać jedynie prawdy uniwersalne, pewną właściwość człowieka, z którą nie powinien walczyć, bo skazany jest na walkę daremną. Jednocześnie owa uniwersalność niemożliwa byłaby bez przeżycia przez Elizę Orzeszkową kilku konkretnych wydarzeń powstania styczniowego, bez próby wytłumaczenia tego zrywu w sposób mityczny i utrwalenia go w porządku historii narodu.

Niedługo przed przystąpieniem przez Orzeszkową do pracy nad Gloria victis ukazują się Echa leśne Stefana Żeromskiego ${ }^{22}$. Tekst ten nieco inaczej niż Oficer rysuje problem bycia Polakiem w rosyjskim mundurze. Opowiadanie jest bardzo ascetyczne, kilka faktów na kilkunastu stronach i przejmujące zakończenie. Wiemy, że Żeromski utrwalił opowieść nieprawdziwą, sensacyjną plotkę, która przydawała tragizmu walce powstańczej. Pierwowzór generała Rozłuckiego, pułkownik Wojciech Ostrowski, dowodził w 1863 roku stacjonującym

${ }^{21}$ P. de Marivaux, Życie Marianny, tłum. J. Rogoziński, Warszawa 1959, s. 133-134.

${ }^{22}$ Opowiadanie powstało latem lub jesienią 1904 r., pierwodruk: Kalendarz Robotniczy na rok 1905 (Kraków). 
w rejonie Piotrków - Opole — Wolbórz 28. Połockim Pułkiem Piechoty. Podobnie jak kilku innych oficerów polskiego pochodzenia, w pułku służył także siostrzeniec dowódcy, chorąży Witold Udymowski, który przeszedł na stronę powstańców. Został skazany na śmierć i rozstrzelany 9 lutego 1963 r. W Echach... Żeromski czyni Rozłuckiego odpowiedzialnym za śmierć bratanka. Tymczasem pułkownik Ostrowski nie tylko nie brał udziału w sądzeniu krewniaka, ale nawet próbował zorganizować mu ucieczkę. W parę miesięcy później na wlasną prośbę podał się do dymisji. Literacki Rozłucki uosabia więc literacki konflikt.

Rozłucki ostentacyjnie wszędzie mówi po polsku. Nie ma kłopotu z pogodzeniem swej polskości z barwami zaborcy. Problem zdrady istnieje dla generała dopiero wtedy, gdy zostanie złamana oficerska przysięga. Poddał się mistyce armii. W niej widzi miejsce dla siebie i swej rodziny, którą utożsamia z wojskiem:

Rodzonego brata drugi z rzędu syn, Jan — mówił generał w zadumie. — Brat mój w sewastopolskiej wojnie pod Małachowym Kurhanem sławnie zginął. Generał-major, mikołajewskich czasów człowiek. Za węgierską kampanię nagrodzony stopniem, orderami, majątkiem w penzeńskiej guberni. Na polu bitwy umierając mnie tych dwóch synów swoich polecił. Jam mu braterskie i żołnierskie słowo dał, że ich na ludzi wychowam, w świat wyprowadzę. No i dochowałem słowa. I dochowałem... 23

„Wyprowadzić na ludzi” Rozłucki rozumie jednoznacznie jako kontynuację rodzinnej tradycji wojskowej. Mały Janek wyrósł w carskim mundurze. Dane mu było jednak uczestniczyć w dziwnej wojnie, w powstaniu Polaków. Wybrał „obowiązek dla swej ojczyzny”. Ów zew krwi przodków jego stryj uznaje za „brednie” i plamę na oficerskim honorze. Sąd wojskowy zadaje zbiegowi zasadnicze pytanie: „Coś zrobił z twoją przysięgą? (...) Przysięgałeś czy nie?”. Sądzący myślą kategoriami struktur i regulaminu armii, mlody porucznik Rozłucki kategoriami uczuć narodowych. Porozumienie nie jest możliwe i nie czas na nie przed obliczem doraźnej sprawiedliwości. Przed egzekucją Jan poleca stryjowi, „żeby mój mały sześcioletni syn, Piotr, był wychowany jako Polak, taki sam jak ja.”. Nie wiemy, jak stryj wypełnił polecenie. Autor zawiesza odpowiedź.

Mundur jest zawsze symbolem. W założeniu ma być zwornikiem jedności organizmu państwowego. Rosja umożliwiała kariery wojskowe czlonkom podbitych narodów. Mieli być wierni przysiędze - to zacierało ich przynależność narodową. Co jednak począć z podziałami wewnątrz rodzin? Czy rosyjski mundur oznaczał renegata?

Armia to system, który wymaga poświęcenia duszy, zwłaszcza w czasie wojny. Zawsze jest to wybór totalny. Nawet jeśli żołnierz może zachować swą narodowość, będzie uczestniczył w sytuacjach tragicznych dla swych rodaków. Dobrym komentarzem do pytań stawianych przez Echa leśne jest wiersz Zbigniewa Herberta, który rozważając pół wieku później zagad-

${ }^{23}$ Ten i następne cytaty z Ech leśnych pochodzą z wydania: S. Żeromski, Dzieła, opr. S. Pigoń, t. 4, Warszawa 1973. 
nienie przynależności narodowej, także zawiesza odpowiedź na pytanie, co ową przynależność warunkuje:

Z faktu używania tych samych przekleństw

i podobnych zaklęć miłosnych

wyciąga się zbyt śmiałe wnioski

także wspólna lektura szkolna

nie powinna stanowić przesłanki wystarczającej

aby zabić

podobnie ma się sprawa z ziemią (...)

chciałbym nareszcie wiedzieć

gdzie kończy się wmówienie

a zaczyna związek realny

czy wskutek przeżyć historycznych

nie staliśmy się psychicznie skrzywieni

i na wypadki reagujemy teraz z prawidłowością histeryków (...)

prawdę mówiąc nie wiem

stwierdzam tylko

istnienie tego związku

objawia się on w bladości

w nagłym czerwienieniu

w ryku i wyrzucaniu rąk

i wiem że może zaprowadzić

do pośpiesznie wykopanego dołu $(. . .)^{24}$.

W sto lat po wybuchu powstania styczniowego powstaje kolejny ważny tekst poświęcony dylematom Polaków przebranych w obcy mundur - Heydenreich Jarosława Iwaszkiewicza. Autor wpisuje się w tradycję stale obecnego w polskiej prozie tematu: czy można zatrzeć w człowieku ślady przynależności narodowej? Czy narodowość może być sprawą wyboru?

Nie ma pewności, jak daleko pozostają od siebie historia i literatura. Czy pierwsza odtwarza, czy kreuje drugą? Czytając teksty literackie, musimy mieć świadomość, że odbieramy wizję artysty, który eksponuje momenty tragiczne. W kreacji artystycznej obcy mundur szkodzi polskiemu ciału — zawsze okazuje się źle dopasowany.

Heydenreich Iwaszkiewicza to opowiadanie przewrotne. Autor przeciwstawia sobie dwie postaci grające nie swoje role: Polaka z Litwy ubranego w mundur rosyjskiego porucznika i byłego carskiego oficera, pół Niemca, pół Francuza dowodzącego polskim oddziałem partyzanckim. Mundur nie jest tu znakiem przynależności narodowej, bo w świecie Iwa-

${ }^{24}$ Z. Herbert, Rozważania o problemie narodu z tomu Studium przedmiotu (1961), [w:] tenże, Wiersze zebrane, Warszawa 1992, s. 150-151. 
szkiewicza (podobnie jak w świecie Orzeszkowej) determinanty pochodzenia pokonać nic można. Mundur jest jedynic informacją o dokonanym wyborze. Udał się on lepiej Heydenreichowi, który z urodzenia nie przynależy nigdzie. Młody porucznik Laudański, Polak i katolik, podobnie jak bohater Oficera, przeżywa swą polskość dopiero w sytuacjach skrajnych. Z wściekłością kłując bagnetem polskiego powstańca, Laudański wykrzykuje po polsku w kierunku Heydenreicha: „Patrz tylko, ścicrwo niemieckie, jak się Polak bije!”25 Świadomość Laudańskiego ulega rozdwojeniu: Polak w rosyjskim mundurze nie może znieść tego, że Niemiec przebiera się za Polaka. Jego własny rosyjski mundur zamienia się w tym momencie w szatę Dejaniry. Już nie za cara i za Świętą Ruś walczy Laudański, staje na chwilę po stronie mitu o walecznym Sarmacie, dla którego Heydenreich uosabia germańską obcość. W momencie wielkiego wysiłku ciała, uczuć i woli wszystko się Laudańskiemu miesza, a raczej (jak powicdziałaby Orzeszkowa) powraca na swoje miejsce. Jeden moment odsłania ową pierwotną, zapisaną przez Boga, matrycę człowieka. Powrót do rzeczywistości jest ciężki. Laudański płacze jak dziecko w ramionach kozaka, który pociesza go w tołstojowskim duchu:

Że braci pozabijał, swoich, Polaków pozabijał? To co? Gołąbku, poruczniku, a jakbyś ruskich pozabijał to co? To także bracia. Wszyscy ludzie bracia, wszyscy na świecie, a zabijają się, strzclają, wieszają, mordują, cisną jedni drugich, prześladują — choć i bracia.

Autor itinerarium, Wincenty Kamicński, zdaje się także stać po stronic prawdy wypowiedzianej przez Podchaluzina. Szczyci się swą ludzką postawą wobec konwojowanych jeńców, nie opisuje żadnych żołnierskich ekscesów, które musiały mieć miejsce podczas długich marszów czy leży zimowych. Żołdacką chciwość ujawnia jedynie w momencie, gdy żałuje, że nie doszło do zdobycia okrętu, który można by złupić zgodnie z prawem morskim.

Kozak Podchaluzin, reprezentujący w tekście Iwaszkiewicza ponadhistoryczny Logos, zdaje się rozumieć prostą prawdę, która brzmi „krew to krew”. Od początku znajomości wypytuje Laudańskiego bez ceremonii o jego polskie pochodzenie. Deprymuje to młodego porucznika mającego opory przed wyznaniem, że pochodzi z podbitego narodu. "Co tam Polak czy nie Polak — (...) cesarzowi służę jak i ty. Obaj jesteśmy rosyjscy żołnierze.” odpowiada Laudański ucickając od tego, co kryje rosyjski mundur.

Maria Janion dostrzega w powstańczej prozie Iwaszkiewicza tonację ironii tragicznej ${ }^{26}$. W Heydenreichu przedmiotem działań Laudańskiego jest pomyślność imperium rosyjskiego. Gdy dochodzi do bitwy, okazuje się jednak, że porucznik nie czuje się do końca częścią owego organizmu, co więcej, musi zabijać tych, z którymi, choć niechętnie, czuje wspólnotę. Nie może poczuć się swobodnie, bo nie dostrzega porządku dziejowego, za który mógłby walczyć.

${ }^{25}$ Ten i następne cytaty z opowiadania Heydenreich pochodzą z wydania: J. Iwaszkiewicz, Zarudzie, Warszawa 1976.

${ }_{26}^{26}$ M. Janion, Inaszkicuicza "nit poustaniaw i ironia czynu dziejowego [w:] O tu'órczości Jarostau'a Iwaszkiewicza, red. A. Brodzka, Kraków-Wrocław 1983, s. 11. 
Każdy czyn obraca się przeciw niemu, wywołuje skutki nieprzewidziane, w każdym razie dalekie od zamierzonych.

Porównując tekst itinerarium Wincentego Kamieńskiego i opowiadania Orzeszkowej, Żeromskiego oraz Iwaszkiewicza, dojść można do jednego wniosku: jakże proste jest życie, jakże skomplikowane sytuacje kreuje literatura.

sztuka stara się uszlachetnić

podnieść na wyższy poziom

wyśpiewać odtańczyć zagadać

zetlałą materię ludzką $(\ldots)^{27}$

Kamieński maszeruje $\mathrm{z}$ armią i nie zastanawia się, co będzie, jeśli jego kula trafi rodaka. Zaskakuje nas swym poczuciem pewności. Jest Polakiem w rosyjskim mundurze i fakt ten nie stwarza sytuacji wyborów tragicznych ani nawet nie pobudza przodka Orzeszkowej do refleksji. Idąc przez Poznańskie, zarzuca żyjącym tam Polakom, że zniemczeli. Sam ma więc poczucie polskości tak silne, iż rozpoznaje odstępców. Nie łączy jednak przynależności narodowej z polityką, jest poza mitami ojczyźnianymi związanymi z Napoleonem. W tekście poprzedzającym sylwę trudno dostrzec konkretną opcję polityczną autora. Natomiast na podstawie fragmentów, jakie wybrał Kamieński, aby wypełnić swój raptularz, zorientować się można, ku któremu z mocarzy Europy kierowało się serce Kamieńskiego:

(...) obaj cesarze [Napoleon i Aleksander I — I. W.] pojawiają się niejednokrotnie na kartach sylwy. (...) Aleksander występuje zawsze jako szlachetny i mądry monarcha, przebaczający pokonanym przeciwnikom i ubolewający nad tym, iż pycha doprowadziła Napoleona do upadku. Specjalnie dobrane cytaty podkreślają życzliwość cara dla Polaków. Wspominając ogłoszoną przez niego konstytucję dla Królestwa Polskiego, Kamieński — za «Kurierem Litewskim» — zaznaczył, że konstytucja ta, zgodna z życzeniami narodu polskiego, stanie się pomnikiem wspaniałomyślności Aleksandra I, który przywrócił Polakom byt polityczny, utracony od roku 1795. Toteż wraz ze zgonem Aleksandra Polacy — jak głosi przytoczona przez Kamieńskiego kantata niejakiej Julii Grodzickiej - stracili w carze ojca. Na szczęście zmarły monarcha zostawił Polakom drugiego ojca w osobie swego brata, złożył bowiem «los nasz w ręce Mikołaja» ${ }^{28}$.

Itinerarium ukazuje świadomość żołnierza, któremu zabrania się analizowania sytuacji ogólnej, gdyż przeszkadzałoby to w wykonywaniu konkretnych zadań. Kamieński ulega natomiast mitowi wojny ojczyźnianej prowadzonej przez Rosję przeciw uzurpatorowi francuskiemu, poddaje się sile munduru rosyjskiego. W okresie wojen napoleońskich Rosja przyjmuje na siebie dziejową misję ratowania Europy. Przyszłość należy do Wschodu, który

${ }_{27}$ Z. Herbert, Zwierciadto wędruje po gościńcu z tomu Rovigo, Wroclaw 1992, s. 42

${ }^{28}$ E. Jankowski, op. cit., s. 76. 
ma odrodzić cywilizację zachodnią. Owo przekonanie o dziejowej roli narodu opierano na niepodważalnej wierze $\mathrm{w}$ potęgę militarną państwa:

Zaborczość i imperializm znajdowały ujście w mistyce wojowania, wyidealizowanym wizerunku żołnierza-bojownika, upajaniu się patosem wojen i zwycięstw. W rozbudowie armii przejawiał i uzewnętrzniał się charakter rosyjskiego państwa totalitarnego.

Od czasów Piotra armia rosyjska należała do najnowocześniejszych i największych w Europie. (...)

Kraj był biedny, ale armia bogata. Pozostawała ona poza zasięgiem krytyki; umiłowanie jej stanowiło synonim patriotyzmu. Naród pozostawał pod silnym wrażeniem potęgi własnej armii. Tej zbiorowej hipnozie ulegli nawet zwolennicy demokracji i przeciwnicy totalizmu. W armii winni służyć ludzie nie tylko silni fizycznie, lecz przede wszystkim mocni duchem i twardej woli. Służba w armii była prawdziwym szczęściem. Cały naród winien pracować na rzecz wojska i oddawać mu wszystko co miał najlepszego. Rodzina winna oddać armii najstarszego syna; hodowca koni - najlepszego konia; fabrykant najlepszą maszynę; robotnik — swoją staranną pracę. (...) Pułk, jego sztandary, jego przeszłość i tradycja były świętością dla żołnierza! (...)

Przegrane bitwy propaganda przedstawiała jako zwycięstwa lub "planowe wycofanie się». Utrwaliło się przekonanie, że armia rosyjska jest niezwyciężona. W roku 1813 doszła ona do Paryża, w 1920 miała dojść do Pirenejów, 25 lat później doszła do Berlina 29 .

W 1805 roku, czyli wtedy gdy Wincenty Kamieński wyrusza na swe pierwsze wyprawy, cerkiew prawosławna rzuca klątwę na Napoleona, a sztandary wojskowe zostają opatrzone w symbole religijne. Prawosławie połączyło się z racją stanu i siłą armii. Rozpoczęła się święta wojna pomazańców bożych. W takiej atmosferze walczył dziadek Orzeszkowej. Nie może nas więc dziwić, że niektóre nierozstrzygnięte bitwy przedstawia jako zwycięstwo Rosjan, zaś tych, w których armia imperium carskiego została pokonana, w ogóle nie komentuje. Armia rosyjska stanowiła narodowy monolit, wojska Napoleona uważano za zbieraninę. Kamieński już na początku swej opowieści informuje, że był jedynym Polakiem w elitarnym pułku. Kontekst wskazuje, że słowa te wypowiada z dumą. Czuł się więc zaszczycony gestem rosyjskiej armii, która przyjmuje w swe szeregi obcych. Ciekawe zresztą, jak udało mu się dostać do pułku uważanego za obrazcowy. Brak cudzoziemców w jego szeregach oznacza, że rzeczywiście przypisywano mu funkcje gwardyjskie, czyli ochronę panującego. Być może rodzina Kamieńskich miała znajomych wśród urzędników wojskowej administracji, być może któryś z przodków także służył w carskiej armii. Na pewno pomogło młodemu Wincentemu świadectwo zatrudnienia w administracji cywilnej. Wstępując do korpusu ofi-

\footnotetext{
29 A. Andrusiewicz, Mit Rosji. Studia z dziejów i filozofii rosyjskich elit, t. 1, Rzeszów 1994, s. 165-166.
} 
cerskiego musiał zapewne wykazać się dowodem szlachectwa i stanem majątkowym. Udział w wielkiej wojnie w określony sposób ukształtował świadomość Kamieńskiego. Jeśli wstępując do wojska był obojętny na sprawy narodowe, takim pozostać już nie mógł opuszczając szeregi armii w roku 1813. Musiał być świadom, że interesy Rosji w ponapoleońskiej Europie nie idą $\mathrm{w}$ parze $z$ interesami Polaków ani na Litwie, ani w kilka lat potem utworzonym Królestwie Kongresowym. Być może nie kojarzył bycia Polakiem z posiadaniem własnego, niezależnego państwa. Być może to właśnie służba w potężnej armii uświadomiła mu, jak silną „opiekunkę” zyskała Polska w 1795 roku. Dlaczegóż by mocarstwo, wcielające w granice swego imperium tak wiele innych narodów, nie miało wcielić doń Polaków? Postawa taka nie oznaczała wcale serwilizmu, lecz uznanie naturalnego porządku rzeczy przez żołnierza, który przyjrzał się imperium od środka. W 1812 r. uznano Rosję za zbawicielkę Europy, zaś gloryfikacja armii sięgnęła szczytu. Zwycięskich generałów za życia ogłaszano bohaterami narodowymi. Kamieński wiedział, jaka kariera otwiera się przed nim. Jednak zrezygnował ze służby zawodowej jeszcze w czasie trwania działań wojennych. Podaje, iż przyczyną „odstawki” był zły stan zdrowia. Być może dano mu odczuć, iż Polak jest niechętnie widziany w gwardii. Dla elementów niepewnych nie było miejsca przy boku cara. Prawdy nie poznamy prawdopodobnie nigdy, pozostaje tylko domysł. Kamieński wrócił do swej roli hreczkosieja i pisania sylwy — dwóch podstawowych czynności polskiego sarmaty. Został dziadkiem jednej z najsłynniejszych polskich pisarek i musiał pośmiertnie zmierzyć się ze swym młodzieńczym wyborem rosyjskiego munduru. Eliza dopisała mu biografię zgodną ze swym wyobrażeniem Polaka, zmieniając mundur carski na napoleoński i umieściła w swym życiorysie jako dopełnienie wizerunku polskiej pisarki-patriotki. „Życiowy błąd” Kamieńskiego został więc naprawiony przez wnuczkę, która w ten sposób uspokajała rodzinne sumicnie i przystosowywała biografię do potrzeb czytelników.

Omawiając itinerarium Wincentego Kamieńskiego, usiłowałam znaleźć w literaturze polskiej konteksty, które powtarzałyby w jakimś stopniu sytuację egzystencjalną dziadka Orzeszkowej. To właśnie wnuczka porucznika keksholmskiego pułku przez przypadek ożywiła tę postać. Wciąż zapalczywie walczymy o wizję przeszłości, która, choć już znieruchomiała, jest najbardziej pełna życia. Literatura dopisuje minionym wypadkom wciąż nowe fabuły. My zaś jesteśmy w sferze literackiego mitu — nie ma sensu bronić się przed nim. Kolisty czas powracających zdarzeń powoduje, że dzieło tworzy własne kategorie duchowo-przestrzenne, silniejsze często od faktów. Opowiadanie historyczne uczy patrzenia na zbiorowość poprzez jednostkę, kreuje misterium jednostki odrywające się wciąż od ołtarza narodu. Kamieński, Orzeszkowa, Żeromski, Iwaszkiewicz opisuja sytuację Polaka, którego nie można uznać za zaprzańca, mimo że odmawia uczestnictwa w narodowej wspólnocie. Ona jednak sama się o niego upomina. Kamieński porzuca armię i wraca do rodzinnej wsi litewskiej. Mamy wrażenie, iż gdyby nie wstrzymał pióra, mógtby rozpocząć poemat opisowy godny Mickiewicza. Karłowicki ratuje powstańca. Rozłucki musi się zmierzyć z polską 
przyszłością swego wnuka. Laudański zrozumie, że z krwią przodków nie ma żartów, nawet jeśli zamaskuje się ją obcym mundurem.

Po lekturze wyżej przywołanych tekstów niełatwo przyjdzie wymawiać słowa: kolaboracja, zdrada, serwilizm. Za każdym z nich stanie bowiem natychmiast szereg opcji politycznych, tragedii osobistych, a czasem po prostu racjonalnych wyborów lub niezależnych od jednostki uwarunkowań rodzinnych. Każda wspólnota narodowa kreuje mity i określa zasady bycia jej członkiem po to, by chronić samą siebie. Jest to naturalny mechanizm podobny do prawa zachowania gatunku. Momenty bezpośredniego zagrożenia narodu generują potrzebę samookreślenia. Wojny napoleońskie i powstanie styczniowe nie tylko w refleksji historycznej, ale przede wszystkim w literaturze, są dobrym polem dla obserwacji procesu budowania definicji słowa Polak. 